\title{
Multidisciplinary co-operation in building design according to urbanistic zoning and seismic microzonation
}

\author{
M. Bostenaru Dan ${ }^{1, *}$ \\ ${ }^{1}$ Universität Karlsruhe (TH), Germany \\ *European School for Advanced Studies in Reduction of Seismic Risk (ROSE), Istituto Universitario di Studio Superiori, \\ Università degli Studi di Pavia, Italy
}

Received: 27 September 2004 - Revised: 24 March 2005 - Accepted: 18 April 2005 - Published: 4 May 2005

Part of Special Issue "Multidisciplinary approaches in natural hazard and risk assessment"

\begin{abstract}
Research and practice in seismology and urban planning interfere concerning the impact of earthquakes on urban areas. The roles of sub-area wide or typological divisions of the town were investigated with the methodology of regression, regarding their contribution to urban earthquake risk management. The inductive data set comprised recovery, preparedness, mitigation and resilience planning. All timely constituted planning types are refound today as layers, as the zoning results are used by differently backgrounded actors: local authorities, civil protection, urban planners, civil engineers. In resilience planning, the urban system is complexly theoretised, then integratedly approached. The steady restructuring process of the urban organism is evident in a dynamic analysis. Although expressed materially, the "urban-frame" is realised spiritually, space adaptation being also social. A retrospective investigation of the role of resilient individual buildings within the urban system of Bucharest, Romania, was undertaken, in order to learn systemic lessons considering the street, an educational environment. (In)formation in the study and decision making process stay in a reciprocal relationship, both being obliged in the (in)formation of the public opinion. For a complete view on resilience, both zoning types, seismic and urbanistic, must be considered and through their superposition new sub-area wide divisions of the town appear, making recommendations according to the vulnerability of the building type.
\end{abstract}

\section{Introduction}

Natural, engineering and social sciences contribute to the evaluation of the earthquake impact on urban areas. Interference areas seismology-urbanism regard:

- assessment techniques, like seismic microzonation ("an estimation procedure of the total seismic hazard from

Correspondence to: M. Bostenaru Dan

(mbostenaru@mariecurie.org) ground motion and related phenomena accounting for the effects of local site conditions" Parvez et al. (2004));

- planning instruments for visualisation and for the strategy development/implementation in both pre- and postdisaster intervention, like urban zoning;

- partnerships models between the actors involved in decision making for risk management.

Local site conditions (ex. near surface geological conditions or topography) can, additionally to distance effects, amplify/reduce the peak ground acceleration (PGA) site value. Building codes in earthquake prone areas account for local site conditions, using a categorisation into site classes of subsurfaces and parameters like sediment infills in irregular geological structures. Long distance earthquakes can have disastrous effects on high-density urban settlements, if alluvial soil deposits amplify the ground motion. The microzonation increasingly contributes to seismic risk evaluation in urban areas. Urban microzonation is researched by the groups of Parvez et al. (2004), Moldoveanu et al. (2004), Panza et al. (2001), Ansal (2002), and Faccioli and Pessina (2003). Parvez et al. (2004) initiated a project towards an integrated expert system, to use seismic microzonation parameters together with information on the earth, environmental, socioeconomic and political systems, in urban planning processes, when elaborating land-use maps, able to provide well estimated seismic inputs for earthquake resilient building design. Parvez et al. (2004) recognised the multidisciplinarity of this work, requiring input from seismology, history, archaeology, geology and geophysics. Parvez et al. (2004) proposed a first level microzonation map using microtremor measurements and a second order one using measured or numerically simulated seismic hazard parameters (PGA, PeakGroundVelocity) relevant for seismic building design in urban areas.

Urban planners might have kept silent because they took only functional and aesthetical aspects, not natural hazards, in account for zoning (Bademli, 2001). Indeed, the 1933 Chart of Athens (CIAM, 1946) stipulated leadership for the 
zoning principle in modern, functionalist cities. Wide application in the second half of the XXth century made the negative side of mono-functional zoning visible (Bohning, 1981). But, the necessity for functional order had leaded to zoning preoccupations before the concept was constituted. Ordering of "urban-life" elements resulted along time as an organisational necessity. In the historic town, the spontaneous division of the urban territory after destination, for population and activities security, found step-by-step the way to institutionalisation. Today, not to negate zoning entered the repertory of urbanism courses (Sandu, 1995a, 1995b, 1997¹), the urban organism being analysed as a complex system:

1. morphologically, with two elements:

- "urban-life" (content): totality of localised urban activities, related into the urban functional structure. This transformation generator is a human activity system, not concentrated on, for example, central or residential activity;

- "urban-frame" (container): totality of spaces corresponding to localisation, related in functionalspatial co-operation into the urban spatial structure.

They become through substantialisation "life-way" and "life-frame", calling inter-/multidisciplinary research constituted on two inter-conditioned layers:

- spatio-functional, on phenomenological "urbanlife" level,

- spatio-perceptual, on physical "urban-frame" level.

The "urban-existence" is a manifestation of the "urbanform". The momentan "urban-existences" ("urbanstates") are concretisations of certain "urban-structures" and build local manifestations in an "urban-situation".

2. (structural)-functionally, the town is constituted based on the "urban-activity" (ex. residing), closely connected to the land-use (ex. residential). The "urban-activity" is preceded by the human "mobile", which evolves during the existence of an urban organism to a totality of "urban-forces". Economic, social, political, aesthetic "urban-forces" lead to space determination through decision/action. The human "mobile" gives the initial impulse, but the activity dimensions an urban space.

3. dynamically, the urban form is a concretisation in time and space, static or dynamic, of the urban phenomenon as a system: spatial forms, forms of territorial organisation and of "urban-life" (psycho-social, economic etc).

Sandu (1995b) proposed a heterogeneous urban model in which a zone has instead of a unique function a unique vocation. Urban zoning ("division of an urban settlement into parts in the functionality of which a unitary character

\footnotetext{
${ }^{1}$ Sandu, A: "Urbanistic doctrines", course notes, "Ion Mincu" Architecture Institute, Bucharest, Romania http://www.iaim.ro/ discipline/?id=1125, 1995a, respectively "Urban structure", http: //www.iaim.ro/discipline/?id=1192, 1995b, "Urban composition", http://www.iaim.ro/discipline/?id=1120, 1997.
}

is recognisable, actively reported to the ambiance", Sandu, 1995b) results as a structural product in the superposition and interpenetration of textures ("sub-systems of the life-frame elements able to respond to the functionally requested situation, an analytic instrument of morphological decomposition of the urban structure in urban theory", Sandu, 1995b) of morphologic elements, thanks to the co-operation process of human activities in the urban territory. The "character-ofa-zone" is defined by all the texture categories encompassed, and by the texture with the highest land-use value. This dominant character is given by the prior function in the zone, which co-operates with the others through the unifying homogeneity of the structure, assuring the heterogeneity of the "urban-life" and "urban-frame". There is a complex urban zoning with operational and organisational value.

Representatively for the multidisciplinary co-operation potential in earthquake impact reduction strategies for urban areas and infrastructure, the zoning as instrument in engineering seismology and urban planning was chosen. Aimed was to learn lessons for the urban system regarding the roles of sub-area wide or typological divisions of the town, based on the role of resilient individual buildings.

\section{Background}

Bucharest lays in the Romanian Plain, centrally on the Moesian Platform. Moldoveanu et al. (2004) described the Bucharester topography as a plane sloped in the SE direction of two river flows, dividing it into morphological units:

- the Dâmboviţa and Colentina meadows,

- the Dâmboviţa-Colentina interstream,

- the Cotroceni-Văcăreşti, Băneasa-Pantelimon plains.

A hazard for Bucharest, at an average epicentral distance of $160 \mathrm{~km}$, are intermediate-depth earthquakes originating in Vrancea, where four tectonic structures intersect: the East-European Plate, and the Moesian, Black Sea, IntraAlpine/Pannonian-Carpathian sub-plates (Soloviev et al., 2000). The socio-economic development of the capital leaded to intensive urbanisation in the centre of Bucharest around 1900 and between the World Wars. The architect Marcel Iancu wrote a manifesto stipulating the organisation of the capital into zones: city centre, central-residential, lowcost housing, and industry; an "utopia" which found way to practice in the 1934 Master Plan for Bucharest (Machedon and Scoffham, 1999). Romanian Modernism adopted the principle of zoning from the urban theory (1933 Charterof-Athens). Functional zoning was a main endeavour to be reached by giving the Master Plan "the power of law" (Machedon and Scoffham, 1999) in 1939, when building regulations were introduced.

In the interwar time, numerous high-rise buildings in "Modernism" style were constructed, to accommodate the growing rich population moved to the city. Employing advanced construction technology of the time was common place, but the possibilities of the materials and systems had 
not been yet researched enough. In 1940 a first strong Vrancea-earthquake $\left(M_{w}=7.7\right)$ affecting Bucharest "tested" these buildings. The reinforced concrete skeleton buildings along the main boulevards in the centre suffered most. In 1977 another strong Vrancea-earthquake $\left(M_{w}=7.4\right)$, leaded to greatest destruction in Bucharest.

Moldoveanu et al. (2004) reviewed seismic microzonations of Bucharest performed after 1940. Seismic microzoning maps were drawn prior to 1977 after Russian model, considering the influence of the surface soil layer and water table level on the building behaviour. Three microzones following the geomorphologic units resulted:

1. the city centre: MacroSeismic Intensity=7-8,

2. the Dâmboviţa and Colentina meadows: $\mathrm{MSI}=8$,

3. the Cotroceni-Văcăreşti, Băneasa-Pantelimon plains and Dâmboviţa-Colentina interstream (rest): MSI=7.

As the 1977 Vrancea-earthquake damage distribution, evaluated by inspection and analysis of the building stock according to the load-bearing structure (Mândrescu and Radulian, 1999) or to the empirically estimated fundamental period (Sandi and Perlea, 1982), infirmed this microzoning map, another was proposed (earthquake intensity according to the damage level, independent of the subsurface geological conditions): a concentrical distribution of the PGA decreasing from centre to periphery (Moldoveanu et al., 2004). The 1977 pattern was infirmed by the PGA values and the spectral content of the instrumental records for the $1986\left(M_{w}=7.2\right)$ and $1990\left(M_{w}=6.9\right)$ earthquakes (Mândrescu and Radulian, 1999). Recently, Cioflan et al. (2004) performed a study based on instrumental observation, interpretation of the site effects, and numerical modelling, calibrated with recorded seismograms. The results were extended to city regions with similar geological structure, dividing the city area into nonconcentrical zones, to which representative response spectra were assigned. The records of a moderate earthquake which struck Bucharest on 27 October 2004 await evaluation.

\section{Methodology}

The built substance in Bucharest was analysed both typologically and sub-area wide, employing urban area survey methods, which allowed identifying the morphological types in the building stock (Bostenaru and Gehbauer, 2004). The "interwar" building class, that constitutes an architectural landmark, but proved to be the most vulnerable to earthquakes, being founded on alluvial soft soil deposits with high ground water level and having in most cases a seismically inadequate conformation, has potential to prove how early multidisciplinary collaboration resulted in better performance. Conclusions drawn through investigation with means of individual disciplines can be put in dialogue in a multi-, inter- or cross-disciplinary manner (Bostenaru, 2004b), as sketched in Fig. 1a. A regression was made (Fig. 1b).

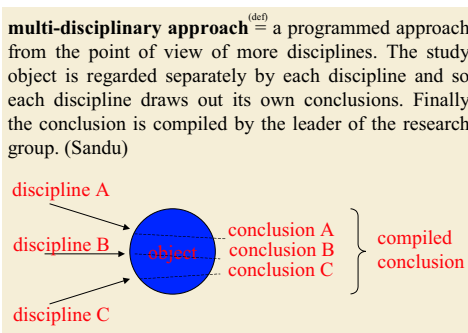

interdisciplinary approach $\stackrel{\text { (def }}{=}$ an approach where the researchers looking to the study object have been trained about the way of approach and the vocabulary of the disciplines with which they collaborate. The programme exists thus before the approach to the problem. The result is an unique conclusion, where the componuts is an whe components originating from a discipline or another cannot be distinguished anymore. (Sandu)

discipline A

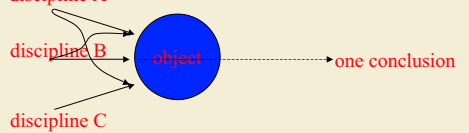

cross-disciplinary approach $\stackrel{\text { (dep }}{=}$ an approach where the on in researcher has got habits from different fields supperposion through doctorate or advanced studies of different formations or through formation in schools with transdisciplinary specific. (Sandu)
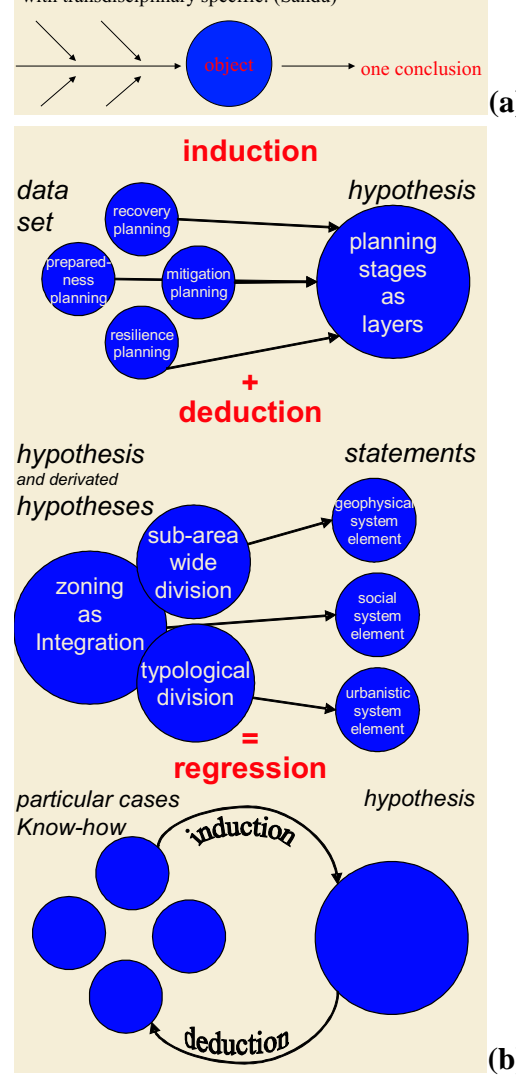

(a)

Fig. 1. (a) Definitions; (b) Regression procedure elements: induction, comprising analysing a data set and formulating a hypothesis based on the observations made (characteristics and criteria were deducted based on analysis of existing projects, while know-how was derived by means of scientific disciplines, see Joedicke (1976)); deduction, where a general hypothesis is drawn out from the one formulated through induction, then hypotheses are formulated, to derive statements for a particular case. 


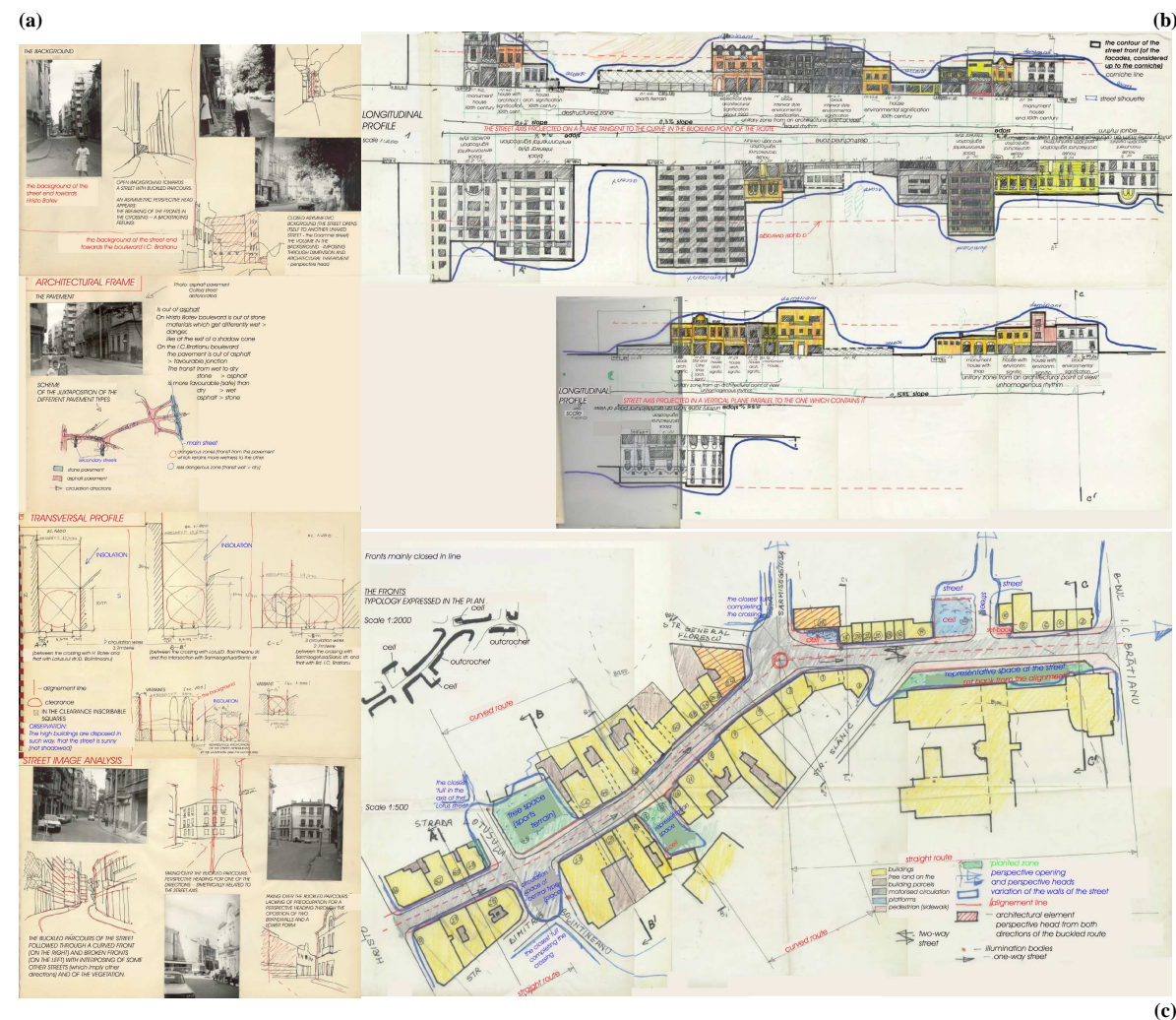

Fig. 2. Architectural frame of a street: (a) floor, background, transversal profile and image analysis; (b) longitudinal profile; (c) parcours.

\subsection{Zoning in planning models for disaster management}

The systemic approach, employed to determine the functional structure of a participative decision model, builds a good communication basis among the participants in the seismic risk management process. The "urban-form" displays an active character in its historic selectivity, resulting in the potential to indicate an urban strategy. The theoretical scaffold therefore is offered by the dynamic interpretation of the town. The elements of "urban-frame" are functionally determined or formal-compositionally determinant, an example for the later being the "perspective dominant", or the rhythm (Fig. 2a). The "urban-form" is more than urban volumetry: an environmental factor complexly related to the life quality, along with the urbanistic conceptions and urban politics, essential for the urban culture. At the level of decision (Fig. 3) or conception, a solution for a certain "urbanexistence" has to take into consideration the spatial manifestation of the "urban-form": the data, the problem approach, solutions, plastic modalities, and the succession of the implementation phases. The data set investigated within the induction process of this research extends the object of disaster management planning through the view on the planning systemic (Fig. 4a). For each planning type a successful international example was analysed, followed by the investigation of the availability of a related approach for Bucharest.

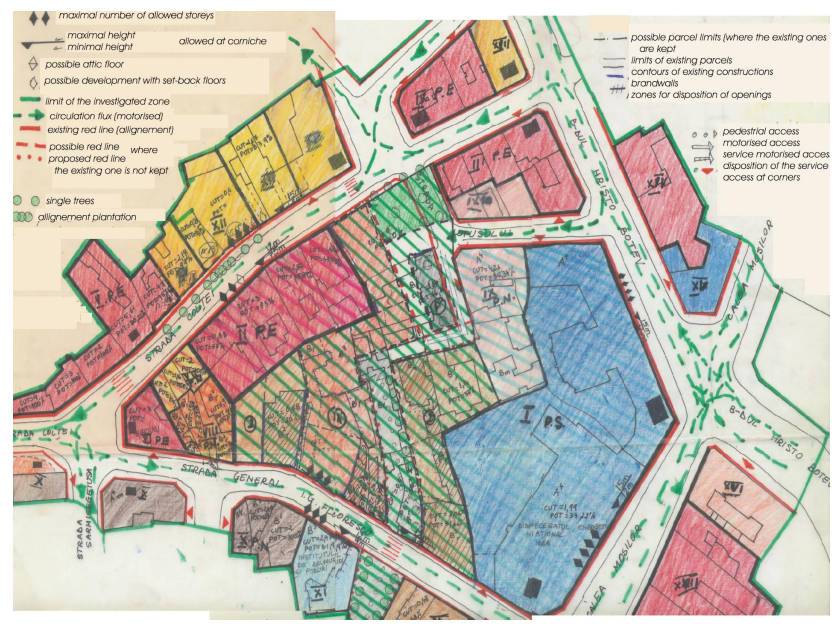

Fig. 3. Example of an urban fine-zoning plan.

\subsubsection{Recovery planning}

At post-disaster reconstruction stage, land-use and physical planning activities are employed. Baroque urban plans, after the 1693 Noto-earthquake (Coburn and Spence, 2002), 1746 Lima-earthquake (Garcia, 1997), 1755 Lisbon-earthquake (Cardoso et al., 2004), 1766 Istanbul-earthquake (Ambraseys and Finkel, 1987) included the development of safe individual building structure types. Urban reconstruction across 


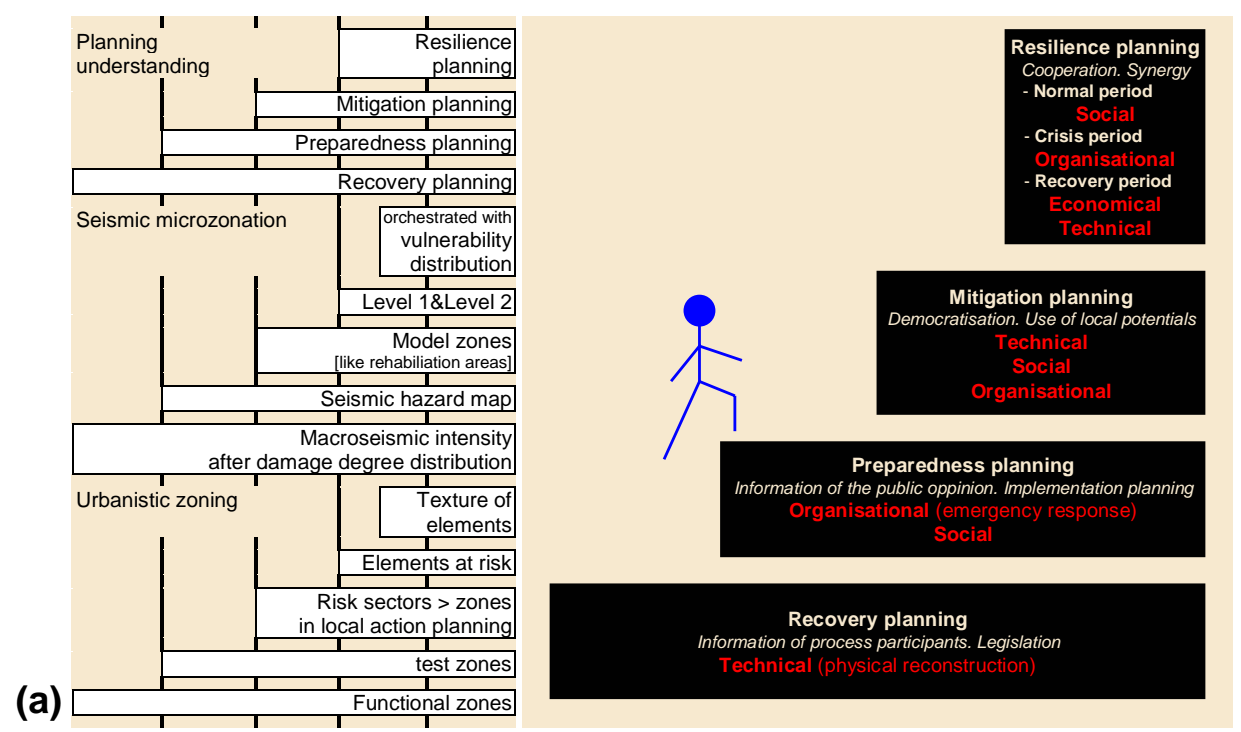

(b)

Fig. 4. Types of planning understanding: (a) their relationship to seismic microzonation and urban zoning; (b) time steps and layers.

the 20th century gives insights into the "long term nature of earthquake protection from the decisions implemented in the aftermath" (Coburn and Spence, 2002):

- early: Pakistan, after the 1935 earthquake (Coburn and Spence, 2002),

- mid: Skopje after the 1963 earthquake (Greene, 1987),

- late: Mexico-City after the 1985 earthquake (Coburn and Spence, 2002).

For Bucharest no such examples are known.

\subsubsection{Preparedness planning}

Emergency preparedness planning is useful for officials, not necessarily experts. Legal frame is in Romania the Government Ordinance "Protection against disasters" (Daraban, 2000). HAZUS (FEMA, 1999) is a well-known US computer aided modular methodology for loss estimation and emergency preparedness planning. Parameters on the potential earthquake, the built substance, and the infrastructure are used to compute scenario physical damage and socioeconomic losses. Secondary events, like fire threat, are included. Central is the capacity spectrum analysis: the performance point, intersection of the ground motion demand spectrum (spectral acceleration versus displacement), and of the structure under lateral load capacity spectrum (pushover curve), is determined, building the input for "fragility curves": the future building type proportion in each damage state. Area parameters (ex. land-use) are transformed into building parameters and individual data of buildings are mapped to areas. Obtained databases are loss estimates for zones, not for building classes.

Computer tools can aid local decision makers in postearthquake disaster staff. Fiedrich (2004) proposed the integrative model EQ-RESQUE to support the prioritisation of intervention zones and the efficient allocation of help-andrescue resources through action proposals. A distributed simulation system connects its two interacting components:

1. simulation of the dynamic disaster environment and of the work of resources;

2. decision process modelling using software agents mathematically optimised with expert knowledge concerning the multiple tasks and the communication structures and decision competences within the disaster staff.

Recent developments include a "Disaster management tool" (Markus et al., 2004), for damage and casualty estimation and detection as well as communication and information support for the disaster management staff. This tool for preevent training and post-event disaster management was tested in an exercise by the civil protection. It also integrates a computer aided damage estimation tool: EQSIM.

\subsubsection{Mitigation planning}

Mitigation planning serves urban earthquake risk management. Collaboration between the involved actors is required to reduce global hazard impact. In the 2003 Earthquake Master Plan of Istanbul, risk mitigation measures coordination is achieved, as actors in each "risk-sector" ("sets of causal relations focused on specific urban risks or vulnerabilities") are activated through the "contingency-plan" that integrates all "risk-sectors" (Balamir, 2004). For each "risk-sector", the nature, problems, management methods, actors, and action proposals are outlined (ex. the scope of "risks in urban texture" includes the determination of risks in the "differential formation of urban fabric", Balamir, 2004). Zoning concerns open space scarcity or incompatible use risks (mitigation: finer land-use zoning). To the "risk-sectors" project packages within both the "contingency-plan" and local action plans correspond. Lines of action are proposed: to involve local 
actors, incl. community, in the urban risk management, to draw agreements and to run sub-project packages (Balamir, 2004). Foreseen "model-zones" represent policy implementation preferences, according to the problems and potentials of the respective area (Balamir, 2004):

- extensive development areas,

- intensive development in seismically safe areas,

- areas endangered by secondary events,

- historical-culturally significant areas,

- rehabilitation areas, highly vulnerable due to seismic or building stock properties, requiring public declaration of their microzonation maps in local action planning.

All planning measures in urban earthquake risk management go from the historical built substance. In the structuring phases of the urban development process, actors from the passive publicity sphere, experts and active affected people are involved. They act within different reference systems, under dynamic, sometimes opposite, conditions. The concept of "retrofit-elements", developed to account for the interdependencies between the constructive, functional and aesthetical characteristics of a building, and a chosen retrofit strategy (Bostenaru, 2004c), proved suitable to serve the organisational and operational structure in model projects within a strategy, to implement retrofit measures in urban areas. The strategic planning approach in Bostenaru (2004c) focused on planning management in the field of experts, with a detailed view on the decision space between scopes, means, function and costs. The "retrofit-elements" build a common denominator for the points of view of all actors participating in the decision process.

\subsubsection{Resilience planning}

Resilience planning aims sustainable urban risk mitigation. The concept of building disaster resilient communities gains acceptance and has already found way into training, in urban risk reduction courses: community based disaster mitigation (Delica and Arambepola, 2000'), or "Housing and earthquakes" (Gülersoy and Özsoy, 2001). Methods in development, addressing the complex dimensions of resilience, are exemplified in the research started by Bruneau et al. (2003) and the RISK-UE project (Mouroux et al., 2004).

Bruneau et al. (2003) provided a conceptual framework for the resilience of communities to earthquake risk: resilience is measured qualitatively in the reduction of failures and their consequences, and of recovery time. The resilience properties are measured by Bruneau et al. (2003) quantitatively as "ends" (system robustness, reaction rapidity) to be reached by "means" (resourcefulness, redundancy of elements/subsystems). Community resilience displays technical, organisational, social and economic dimensions (Bruneau et al.,

\footnotetext{
${ }^{2}$ Delica, Z, Arambepola, NMSI: Workshop on urban disaster mitigation, Karlsruhe University, Germany, course material, Asian Disaster Preparedness Center, Bangkok, Thailand, http:// www.adpc.ait.ac.th, 2000.
}

2003). The development and application of quantitative measures in a case study of the Memphis, Tennessee, water delivery system (Chang and Shinozuka, 2004) proved the Bruneau et al. (2003) resilience framework, employed to analytically determine the resilience of different units, as a valuable guidance for mitigation and preparedness.

The RISK-UE project developed a modular methodology for earthquake scenario assessment through global impact analysis, accounting for the distinctive features of European cities with regard to current and historical buildings, as well as their functional and social organisation. The project was organised in work packages, for either methodologies, or the application to the participating cities: Barcelona, Bitola, Bucharest, Catania, Nice, Sofia, Thessalonica. Seismic zonation was addressed in a work package concerning probabilistic and deterministic earthquake hazard evaluation (Faccioli and Pessina, 2003). Urbanistic zoning was addressed in the work package "Urban System Analysis" (Masure and Lutoff, 2003) through the "Urban-System-Exposure" methodology: system components and their functionality, then the "elements-at-risk", their indicator-quantified exposure, and the vulnerability factors were analysed, leading to the identification of problems and opportunities. The spatial distribution of strategic or vulnerable elements was mapped. The elements were ranked according to their role in the system during normal, crisis and recovery periods. After appropriation of the problems posed by seismic risk, "management-plans" and "plans-of-action" are proposed for strategic implementation by decision-makers through land-use decisions.

\subsection{Interdependencies between planning layers}

Morphologically the "urban-frame" is composed out of the following sub-frames:

- physical:

- natural environment, linked to natural hazards,

- built environment, linked to vulnerability;

- economic;

- psycho-social;

- juridical-administrative, linked to the preparedness planning and legislation;

- historical-cultural, linked to the historic selectivity of the textures in restructuration.

Since the transformation generator is the "life-way" and not the "-frame", only changes in activities can result into risk mitigation. Behaviour changes need inhabitants' support. The more accentuated the voluntary character in the restructuration process, the role of experts, of decision makers, and of public opinion grows. Bostenaru (2004d) explored the contribution of participatism to disaster mitigation, when this concerns earthquake impact on urban settlements, through the support provided to multi-criteria decision in retrofit. Models paying consideration to the co-operation among different actors implied in the planning process were selected 
for analysis. In a historic perspective spanning half a century, two generations of inhabitants' implication in politicsdemocratisation-urbanism became evident: participation and its successor, communication. The participation is based on a central decision process leading to a solution controlled and steered by the political-administrative system. The communication is characterised by simultaneous decisions taken by politics and administration in co-operative procedures (Bostenaru, 2004d). In all investigated cases it could be talked of successful learning and of the improvements in the professional debate. The historically investigated stages can be remet in a single contemporary approach, the "Internationale Bauausstellung Emscher Park“ (IBA, 1999), proving that the transition stages from participation to communication are layers in any democratic planning.

Layers can be distinguished in disaster management planning, too: recovery, preparedness, mitigation and resilience (Fig. 4b). Various steps were constituted along time:

- Skopje, Macedonia (FYR):

- Re-shaping recovery planning after the 1963 earthquake (Greene, 1987),

- mitigation planning in the earthquake Master Plan 2001-2020 (Savic, 2001);

- Bursa, Turkey:

- historical recovery planning after the 1855 earthquake (Coburn and Spence, 2002),

- mitigation planning today (Bademli, 2001).

Central to recovery planning stays the technical dimension: physical reconstruction. In preparedness planning the emergency response ability of organisation, and herewith the organisational dimension stay in foreground. Decision being an element in the risk management process, both the processural and the social dimension of risk management are considered on decision level. In mitigation planning, natural (technical dimension) and human (social dimension) factors are considered in the framework of ex. "risksectors". The social dimension is highlighted through the democratic involvement of the whole society in risk management. Along the organisational dimension, the planner has a moderator-role, in a new understanding of planning. In the "Urban-System-Exposure" methodology different "homogenous-units" (zones) within the investigated city can be comparatively related on the denominator of "elements-at-risk". The problems and opportunities, as well as the elements' vulnerability, lead to system resilience: physical, human, functional, economic and social. In normal period the classification of the "elements-at-risk" serves priority setting for pre-earthquake retrofit actions. Appropriation phases, within a local participative framework, of the problem posed by seismic risk, highlight the social dimension. In crisis periods, there is an organisational demand for emergency systems. In recovery periods economic resources are needed. Attention should be paid for "turning reconstruction into future protection" (Coburn and Spence, 2002), where the technical dimension counts. Both mitigation and resilience planning show similarities to the layer corroboration in the IBA Emscher Park (1999): action planning processes are expected to be initiated by means pilot projects. Methods and tools developed in model projects will find future way in urban practice.

\section{Results}

Research on how to facilitate actors' collaboration (Bostenaru, 2004e) considered the timing in actors' preferences on intervention layers in urban seismic rehabilitation: town, building and element. Orientation means for actors' interaction, like the "retrofit-elements" in buildings, were designed on each level. The implementation of the decision model was exemplified in a strategic plan for an urban intervention towards the reduction of earthquake hazard impact. The proposed risk management in urban textures presents similarities to the mitigation planning example discussed in this contribution: urban texture zones differentiated in the plans are sustained through long-term physical policies for redevelopment, like differential property taxation.

Urban earthquake impact results from the interaction of three complex systems:

1. the earth system, consisting of

(a) regional geologic factors: seismic source and seismic wave propagation;

(b) geometric-physical local geology conditions, accounted for in seismic microzonation;

Using geological, geophysical and geotechnical data, as well as source and propagation models, pre-event seismic microzonation can be performed and extrapolated in time and location. Seismic records are a quantitative basis for urban planning and building design.

2. the social, economic and political system from normal, as opposed to crisis and recovery, periods, accounted for in building codes and disaster regulations;

3. the anthropised system (buildings and infrastructure), accounted by vulnerability studies, incl. specific materials and technologies, and seismic planning.

\subsection{The role of zoning in the geophysical system}

Seismic building damage depends on the ground motion (amplitude, frequency, shaking duration) and the building structure (resonance period related to subsoil local transfer) characteristics. For engineering studies, the spectra and accelerograms express best the seismic site response. Displacement spectra model earthquake actions on buildings: the displacement dimension correlates to damage and the period dimension to the relationship ground-motion-frequency-content/fundamentalvibration-period-of-the-building (Fig. 5a). The destruction amount in Bucharest was attributed mainly to the so-called 

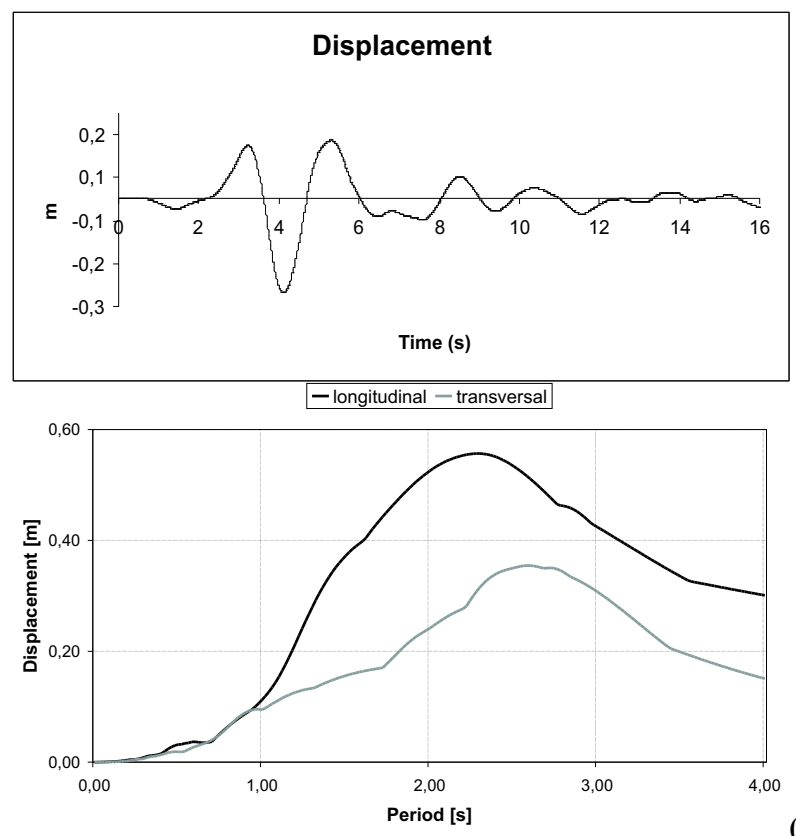

(a)

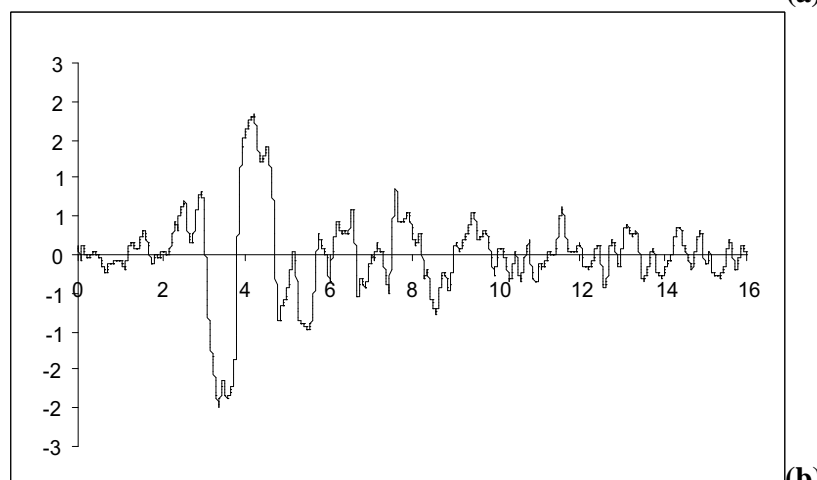

(b)

Fig. 5. (a) Displacement seismogram (top) and spectra (bottom); (b) Accelerogram of the 1977 Vrancea-earthquake (using parameters from Ambraseys et al. (2002)).

"Mexico-city" effect on alluvial soil deposits. This layer amplified the seismic site response in the period range critical for the pre-damaged interwar buildings (Lungu et al., 1994), with structures designed for gravitational loads only, altered unfavourably to later function changes. The first systematic measurements of ambient seismic noise in the centre of Bucharest concluded that damage degree in the 1977 earthquake increased with the fundamental period of the structure (Sandi and Perlea, 1982). Bonjer et al. (1999) obtained in a site response experiment local soil resonances of $1-2 \mathrm{~s}$ (peaks $\sim 1.4 \mathrm{~s}$ ). Flexible $6-12$-storey reinforced concrete buildings are expected to shift their fundamental resonance towards the strongest site resonance (Ambraseys, 1977), especially in weakened pre-damaged structures (cracked period). The fundamental period of the flexible Modernism skeleton structure buildings was $0.7-1.6 \mathrm{~s}$, a range which corresponds to the spectral maximum (Fig. 5a) obtained for the only reliable accelerogram recorded in Bucharest during the 1977 Vranceaearthquake (Fig. 5b), while rigid load-bearing structures with masonry walls or reinforced concrete structural walls with $0.2-0.7 \mathrm{~s}$ fundamental period (Moldoveanu et al., 2004) were lightly damaged.

The foundation ground in Bucharest is classified in (Moldoveanu et al., 2004):

- alluvial-proluvial deposits (Cotroceni-Văcăreşti plain, Dâmboviţa-Colentina interstream);

- diluvial deposits (Dâmboviţa terraces);

- alluvial deposits (Dâmboviţa and Colentina meadows);

- artificial fills (Dâmboviţa-Colentina interstream).

The hydrostatic level varies from $1-5 \mathrm{~m}$ in the meadows to bellow $10 \mathrm{~m}$ in the plains. Soil-structure interaction is important also for the problematic foundations of these buildings (Bostenaru, 2004a).

The architectonic landmarks of Modernism in Romania, located on unfavourable sites according to seismic microzonation, would perform bellow satisfactory in an earthquake with similar spectral content to the 1977 one. Therefore, Mândrescu and Radulian (1999) see they key for understanding earthquake patterns in comparing vulnerability distribution maps with seismic microzonation and damage distribution maps.

Rules for seismic design were first introduced in Romania after awareness raised by the damage in the 1940 earthquake. A practicing engineer, leading one of the enterprises which implemented innovative structural and construction management solutions for this building type, documents (Prager, 1979) successful engineer-architect collaboration during the boom-time of constructing in Avantgarde style (Bostenaru, 2004a). Although interrupted during the economic crisis, this was both incentive and opportunity raiser for creative design and technical solutions in constructing with a material new that time. This co-operation made many reinforced concrete building initiatives possible. Far from adopting the simplest ideal conformation, usability and aesthetics strongly influenced the structural solution. An array of success stories is documented in Fig. 6 and Table 1.

\subsection{The role of zoning in the social system}

Morphologically, the spatio-perceptive elements of the "urban-frame" transpose in the urban territory the activity system. Each decision and each action is transposed materially in space occupation. Bucharest saw 1920-1940, in two decades of intense building efforts, the construction of the buildings which give its face of today, many of them designed by world-class architects. It was a unique time when not the aesthetics governed, but a solution to the problems of the society: the lack of housing suiting the life style. Urban legislation reacted with the 1934 Master Plan to the anticipated impact of economic development in interwar Romania on urban areas. The land-use occupancy ratio was prescribed for the central zone. Numerous multifunctional (housing, office, shops, cinemas) complexes were constructed making maximum land-use, allowed only with $30 \%$ of the total admitted building volume at ground level. The multiple usage of the 
space through building in the height in urban agglomerations is a concretisation form of the "fight-for-space" of "urbanforces“ (Sandu, 1995b) in opposition. The properties of the urban space result from the interaction of social groups modelling it. Bucharest's central luxurious residences illustrate how a move of interests of the social groups in the urban territory has a parcours, which it follows till finding place.

The centre is a special case of the character-of-a-zone. A texture completes spatially another texture when, through organised superposition, they generate mixed assemblies with complex character. In subdivisions of the central area either residential/central functions dominate or dominant residence co-operates with central functions. On the N-S boulevard in Bucharest a spatial co-operative superposition of urban textures with complementary character contributes to a specific zonal ambient. The commercial, cultural, administrative, and residential space complexity expresses a necessity. The afferent space is conditioned through its occupation reported to the "life-way", with its socio-economic development and the natural environment conditions in the context of a continuous intervention process in time. Retrofit methods innovative in international context were proposed after the 1977 Vranceaearthquake (Sandi et al., 1982), but remained on paper until in the frame of co-operations within the field of earthquake engineering attention was raised to the conservation of existing buildings, to complement the development of seismic codes for new buildings. Daraban (2000) dealt with methodological and legislative guidelines in the rehabilitation of the existing building stock in Romania (Table 2). The contemporary approach follows strategic means. Instead of the whole city, intensive zones were identified, and for these detailed implementation solutions are elaborated through demonstrative projects. These "test-zones" have different size in the corresponding projects (SFB 461, Wenzel, 1997 and RISKUE, Mouroux, et al. 2004) and were chosen according to the damage occurrence documented in the 1977 earthquake. Interests like building for speculation met the "exigency" ("the enounce of a user necessity regarding the construction", Daraban, 2000) for safety in residential buildings, the legislative "resistance and stability" requirement. Today a "userexigency" motivates for urban renovation, if the performance level is below new user requirements (Daraban, 2000).

\subsection{The role of zoning in the urbanistic system}

In resilience planning, consideration for the morphological town elements, "urban-life" and "urban-frame", and the role of the town in a wider urban area can be recognised. The earthquake vulnerability of the system is evaluated through an analysis of the system functionality. A system is defined analytically through its elements and their relationships. The role of the elements in the system differs, according to their "urban-frame" value (perceptional aspects like the city image and identity), and their role in the "urban-life" (activities in the town or the function of the town in context). In an integrated seismic risk study, the city is seen an open system, connected with its environment, and approached as an

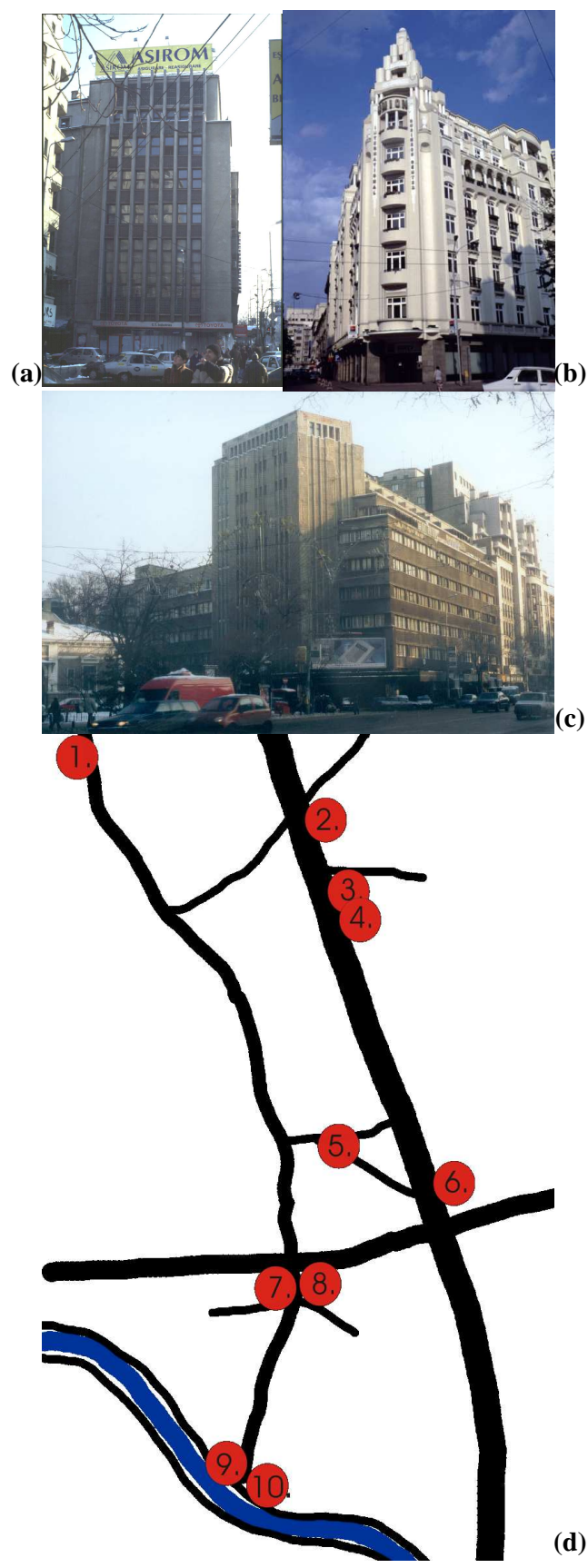

Fig. 6. Examples of buildings designed in successful co-operation between engineers and architects, which proved to have earthquake resilient features despite their high irregularity, resulted from respecting the urban zoning rather than site conditions: (a) Casa Magistraţilor, (b) "Union" hotel, (c) ARO-building (today "Patria“); (d) Location of the examples in Table 1: 1. CAM-building; 2. The magistrates house; 3. ARO-building; 4. "Ambassador" hotel; 5. "Union" hotel; 6. "Dalles" foundation; 7. Block-of-flats on Calea Victoriei 23; 8. Block-of-flats on Calea Victoriei 68/70; 9. Blockof-flats at the Calea Victoriei/Splaiul Independentei crossing; 10. Block-of-flats on Splaiul Independentei.

integrated part of the seismic risk scenario. Seven RISK-UE components mix the morphological, functional and dynamic 
Table 1. Examples of successful reinforced concrete (RC) building design on difficult site conditions (details from Prager (1979)).

\begin{tabular}{|c|c|c|c|c|c|}
\hline No. & Building name & Architecture & $R C$ project & Execution & Description \\
\hline$\overline{11}$ & CAM Palace & $\begin{array}{l}\text { Duiliu } \\
\text { Marcu }\end{array}$ & Mihail Hangan & & $\begin{array}{l}\text { New technical prescriptions were strictly applied. Architecturally it is characterised by modernist asym- } \\
\text { metry and a subtle neoclassicism in the U-shaped plan, as well as high quality finishings. }\end{array}$ \\
\hline 2 & $\begin{array}{l}\text { „The Magistrates“ } \\
\text { House“" }\end{array}$ & $\begin{array}{l}\text { Duiliu } \\
\text { Marcu }\end{array}$ & $\begin{array}{l}\text { Mircea } \\
\text { Gheorghiu }\end{array}$ & $\begin{array}{l}\text { Mircea } \\
\text { Gheorghiu }\end{array}$ & $\begin{array}{l}\text { Commercial, office, residential use. At the first floor a festivity hall required for Vierendel frames and } \\
\text { beams in order to sustain the masonry walls of the upper floors. Carefully made execution. The architec- } \\
\text { ture is related to that of a building by Leopold Medilanski, currently in retrofit. }\end{array}$ \\
\hline 3 & $\begin{array}{l}\text { Cinema block of } \\
\text { flats "Patria" }\end{array}$ & $\begin{array}{l}\text { Horia } \\
\text { Creangă }\end{array}$ & $\begin{array}{l}\text { Cristea } \\
\text { Mateescu and } \\
\text { Ştefan } \\
\text { Mavrodin }\end{array}$ & & $\begin{array}{l}\text { There were difficult static problems for the balcony and roof of the cinema hall. The lateral and gravita- } \\
\text { tional loads are carried by frames forming both the walls and the roof (with parabolic arcs) of this hall. } \\
\text { Missing other lateral load resistance prescriptions, the frames were computed for wind loads, although } \\
\text { the hall, half located in the basement and placed in a building interior was very lightly solicited this way. } \\
\text { Cristea Mateescu used the method "Cross", introduced in Romania in that year (1934). These computa- } \\
\text { tions leaded to sufficient stability at any lateral forces. The balcony is the most important construction of } \\
\text { this kind, executed not just in RC but also steel. The foundation lays higher than at neighbouring buildings. } \\
\text { This work was a milestone of modern RC buildings. It marked the begin of reshaping the forms of the } \\
\text { boulevards. The expressive composition contributed to the rhythm of the boulevard with a tower, which } \\
\text { became a typical Romanian modernist corner solution. }\end{array}$ \\
\hline 4 & "Hotel & $\begin{array}{l}\text { Arghir } \\
\text { Culina }\end{array}$ & Dumitru Marcu & $\begin{array}{l}\text { Tiberiu } \\
\text { Eremia }\end{array}$ & $\begin{array}{l}\text { The entire assembly presents a judicious structural solution: side bodies, free façade on the courtyard of the } \\
\text { upper storeys, decreasing size of the upper storeys. Recesses above a certain "shade"-height were dictated } \\
\text { by the urban regulation. Architecturally the building has a monumental appearance, due to symmetry and } \\
\text { presence of vertical elements. Urbanistically is a rhythmic point along the boulevard through the set-back } \\
\text { courtyard. It forms an impressive complex with the "Patria" building. }\end{array}$ \\
\hline 5 & Hotel "Union" & $\begin{array}{l}\text { Arghir } \\
\text { Culina }\end{array}$ & Emil Prager & \begin{tabular}{|l|} 
Emil Prager \\
\end{tabular} & $\begin{array}{l}\text { Short terms for execution and delivery leaded to construction and installation works made simultaneously. } \\
\text { The central situation of the parcel generated hard organisation conditions. A special RC work was done } \\
\text { because of the higher laid foundation of the neighbouring building: the new foundation was made through } \\
\text { a tunnel gallery. Strongly damaged during WWII ( } 4 \text { upper floors and } 2 / 3 \text { of the surface of the building), it } \\
\text { could be repaired without further strengthening. }\end{array}$ \\
\hline 6 & Dalles foundation & $\begin{array}{l}\text { Horia } \\
\text { Teodoru }\end{array}$ & $\begin{array}{l}\text { Aurel Beleş and } \\
\text { Dim Marcu }\end{array}$ & Emil Prager & steel for huge halls \\
\hline 7 & $\begin{array}{l}\text { Block of flats on } \\
\text { Calea Victoriei } 23\end{array}$ & $\begin{array}{l}\text { L. } \\
\text { Negoiescu }\end{array}$ & Jean Hascal & \begin{tabular}{|l|} 
M. \\
Calmanovici
\end{tabular} & $\begin{array}{l}\text { The exterior columns of the skeleton start from the ground floor, being sustained by a concrete wall which } \\
\text { constitutes the exterior wall of the basement and which bears the loads from the ground. }\end{array}$ \\
\hline 8 & $\begin{array}{|lr|}\text { Block-of-flats r on } \\
\text { Calea } & \text { Victoriei } \\
68 / 70 & \end{array}$ & \begin{tabular}{|l|l} 
Nicolae \\
Nenciulescu
\end{tabular} & Luigi Cora & Emil Prager & $\begin{array}{l}\text { It has two basements and a soft storey. A RC dome over the ground floor widely opened to Calea Victoriei } \\
\text { with glass bricks corresponding to the lighting courtyard of the } 7 \text { upper storeys. This hole had } 10 \mathrm{~m} \text { span. } \\
\text { For this purpose a "wall-beam" was constructed within the mezzanine wall of the façade. Other special } \\
\text { problems were provided by the functional use, including parking on the whole basement area, residences } \\
\text { and offices in the upper floors, commercial use on the ground floor. Executed very carefully, it proved to } \\
\text { be easy to maintain. }\end{array}$ \\
\hline 9 & $\begin{array}{l}\text { Block-of-flats at } \\
\text { the Calea Victoriei } \\
\text { - Splaiul Indepen- } \\
\text { deţei crossing }\end{array}$ & \begin{tabular}{|l|} 
Nicolae \\
Cucu and \\
Gheorghescu
\end{tabular} & Mihail Hangan & Jean Hascal & $\begin{array}{l}\text { It consists of two building wings, one of them next to Splaiul Unirii (the street along the Dâmboviţa River). } \\
\text { It was founded on a general mat at } \sim 6 \mathrm{~m} \text { depth, the one of ground water. A special solution was adopted } \\
\text { for a ground column which was removed, being replaced by a RC frame element made with fast casted } \\
\text { cement, with only } 12 \mathrm{~h} \text { of hardening. }\end{array}$ \\
\hline 10 & $\begin{array}{|lr|}\text { Block-of-flats r on } \\
\text { Splaiul } & \text { Indepen- } \\
\text { denţei } & \end{array}$ & $\begin{array}{l}\text { Petre } \\
\text { Antonescu }\end{array}$ & Dim Marcu & $\begin{array}{l}\text { Tiberiu } \\
\text { Eremia }\end{array}$ & $\begin{array}{l}\text { Special solution to avoid having columns at ground floor level: } 3 \text { column arrays at upper floors and only } \\
2 \text { at lower floors: RC Vierendel columns over the ground floor in the whole height of the mezzanine - } \\
\text { no problems with openings in the party walls of the mezzanine. Columns to the lighting yard were also } \\
\text { discontinued at the level between mezzanine and first floor. They are sustained by a high beam "macaz cu } \\
\text { tirant". The skeleton of the upper floors was computed after the German circular from year } 1925 \text {. }\end{array}$ \\
\hline
\end{tabular}

town elements. The "multi-task operation [of resilience planning] requires the integration of programs prepared in distinct areas and aims to generate a lasting synergy based on coordination" (Balamir, 2004). Urban zoning confirms the integration as vital necessity in the existence of the urban organism. Functional integration occurs at the level of:

- object functions: analysis of a functions complex to which the built substance responds,

- urban functions and programmes.

Sandu (1997) affirms that "out of all urban spaces, the street is available as the most adequate location for the affirmation of the urban character." The urban frame of a street is defined by its floor, background and fronts (Fig. 2a). Analytically, the analysis of this frame begins with that of its profiles and parcours (Fig. 2). The spatial manifestation of the street results from a combination of factors: functionality, climate and terrain conditions, historic existence, conceptual design and last but not least "life-way" (Sandu, 1995b). In the Master Plan of Bucharest, as the Charter of Athens 1933 (CIAM, 1946) stipulated circulation as functional zone, the street remained a formal expression of functionality. Another essential element of the Master Plan of Bucharest was the circulation network. Circulation control was expressed in the shape of street fronts, for which concepts of style were included (Machedon and Scoffham, 1999). For the centre, the cornice height limit was fixed, except at corners, leading to set-back upper floors. The inversing of the positive and negative space, placing constructed volumes "in-the-green" was not undertaken.

Restructuring urban actions are reordering efforts of the elements into textures, aimed at the functionality of the "urbanstructure". After the 1977-earthquake a number of damaged buildings were repaired and strengthened, while those collapsed were replaced in multi-disciplinary cooperation. For changes imposed by the partial collapse of some buildings acceptable architectural solutions in retrofitting were found, and solutions which might seem economically inefficient were adopted in order to preserve as much as possible from these historical-architecturally relevant buildings (Fig. 7), since the completion of the N-S Boulevard fronts leaded to "an architectural sequence of modernist buildings (...) without equal in Europe" (Machedon and Scoffham, 1999). In Table 3 the impact of an urban restructuration proposal for a street is studied. The vulnerability of a street affects its resilience in all four dimensions. The N-S main boulevard in Bucharest is characterised by typological unity. 
Table 2. Correspondence of qualitative exigencies to derived provisions for urban planning, using Daraban (2000) and MLPAT (1994).

\begin{tabular}{|c|c|c|c|}
\hline Type & Year & Content & Urbanism exigencies \\
\hline \multirow[t]{5}{*}{$\begin{array}{l}\text { national } \\
\text { standard }\end{array}$} & 1972 & $\begin{array}{l}\text { Design principles for constructions in earth- } \\
\text { quake prone areas }\end{array}$ & \multirow{2}{*}{$\begin{array}{l}\text { - proper choice of the site, } \\
\text { - rational conformation of the assembly, mass and volume distribution, } \\
\text { - corresponding materials, } \\
\text { - economically feasible seismic measures, } \\
\text { - in geologically instable regions, respect of microzonation maps/studies, } \\
\text { - no foundation on inadequate terrains. }\end{array}$} \\
\hline & 1988 & $\begin{array}{l}\text { Foundation terrain classification and identifi- } \\
\text { cation }\end{array}$ & \\
\hline & 1971 & The seismic intensity scale & none \\
\hline & 2000 & $\begin{array}{l}\text { Proof principles of constructions security: at } \\
\text { functional, natural, climatic, seismic and ex- } \\
\text { ceptional causes }\end{array}$ & none \\
\hline & $\begin{array}{l}1991- \\
1993\end{array}$ & $\begin{array}{l}\text { Seismic zoning and the microzonation of the } \\
\text { territory of Romania }\end{array}$ & none \\
\hline \multirow[t]{3}{*}{$\begin{array}{l}\text { government } \\
\text { decision }\end{array}$} & 1990 & $\begin{array}{l}\text { The reduction of damage risk in constructions } \\
\text { affected by earthquakes }\end{array}$ & $\begin{array}{l}\text { the obligation to perform geotechnical studies on parcels next to buildings, accounting for the type and the } \\
\text { importance of constructions and of the designed construction system }\end{array}$ \\
\hline & 1991 & $\begin{array}{l}\text { Strengthening measures on earthquake dam- } \\
\text { aged buildings }\end{array}$ & $\begin{array}{l}\text { keeping an inventory of damages regarding the resistance and stability of constructions on geographical zones } \\
\text { and local sites }\end{array}$ \\
\hline & 1994 & $\begin{array}{l}\text { Regulation regarding the establishment of the } \\
\text { importance category of the construction }\end{array}$ & importance categories and classes influence the justification in the site choice \\
\hline $\begin{array}{l}\text { government } \\
\text { ordinance }\end{array}$ & 1994 & Protection against disasters & none \\
\hline law no. 10 & 1995 & The quality in constructions & $\begin{array}{l}\text { 1. "geotechnical mappings and hydrologic and geologic analyses": the quality of the urban site, the imposed } \\
\text { general founding conditions, the determined height of ground water. The impossibility to construct or furnish } \\
\text { in zones exposed to natural risk is considered. Only interventions limiting negative effects can be admitted. } \\
2 \text { "expertise of the building stock targeting the evidence of its characteristics and uses": the constructive system } \\
\text { of the buildings, the maintenance state and age (buildings pre-damaged by earthquakes, physical wearing), } \\
\text { volumetric configuration, height, distances between the buildings. }\end{array}$ \\
\hline $\begin{array}{l}\text { Romanian } \\
\text { seismic } \\
\text { code }\end{array}$ & 1992 & P $100-92$ & $\begin{array}{l}\text { - choice of sites with favourable seismic behaviour, } \\
\text { - conformation of assemblies, correlated to structural implementation, for a good seismic behaviour, } \\
\text { - choice of the site to respect the economic component, } \\
\text { - height stated according to functional and urbanistic consideration, } \\
\text { - installations and equipments included from design on in seismic categories, } \\
\text { - for buildings the damage of which has particularly severe consequences, the categories of excluded sites will } \\
\text { be précised from begin, naturally difficult sites have to be optimised through specific measures, if not avoided. }\end{array}$ \\
\hline
\end{tabular}

Residential buildings feature the same structural type of reinforced concrete skeleton. Due to their Modernist style, they belong to a common architectural typology. This building class considered displays a socio-architectural type with a certain typology of the housing unit developed that time. Finally there are common characteristics of the type concerning the ownership pattern and eventual economic strategies resulting therefrom.

\section{Perspectives}

Physical vulnerability is well assessed by displacement spectra. Therefore their shapes need a further study. Organisational and social vulnerability cannot be assessed with help of displacement spectra. Economic vulnerability can only be limitedly assessed this way, as it can be taken into account by scaled curves for the yield and post-yield periods, which stay for moderate and strong damages respectively.

Predictive approaches to urban risk management can be classified as:

1. Seismic hazard and engineering vulnerability assessment (seismic properties of sets of individual buildings are investigated and recommendations for retrofitting made according to technical and economic criteria):

- Qualitative methods: field investigation by experts, ex. Rapid Visual Screening (ATC-21, 1988), resulting in applications like HAZUS (FEMA, 1999).
- Quantitative methods: seismic damage potential assessment derived from structural analysis, exemplified by Glaister and Pinho (2003).

2. Urban system vulnerability analysis (human, material and financial loss models based on physical damage scenarios), leading to technical measures to be taken by authorities through planning instruments. The RISKUE "Urban-System-Exposure" analysis completes this practice with immaterial town morphology elements.

Glaister and Pinho (2003) proposed, alternatively to the capacity spectrum analysis, a simplified deformation-based urban vulnerability assessment methodology. Qualitative damage limit states are expressed using analytic relations between building displacement capacity and height. Empirical elastic-period/equivalent-height relationships translate the deformation capacity curves from height to period dimension. Demand curves are damped displacement response spectra. The intersection of the capacity and demand curves delimits building height classes failing limit states. An approximate joint probability density function completes the obtained cumulative distribution, accounting for the uncertainty in the geometrical, material and limit-state building class properties (Crowley et al., 2004).

While in recovery, preparedness, or mitigation planning, a sub-area wide division is useful, the method started by Glaister and Pinho (2003) is one of the few approaches where a typological classification is used. Also the RISKUE "elements-at-risk" (Masure and Lutoff, 2003) are classified strategically, showing similarities to the approach of 
Table 3. Normalised indicator ranges for the impact of actions to restructure the urban structure on a street after an urban zoning plan in Bucharest centre, chosen value (bold), scores for the environment for actions and measures to lower the negative action impact.

Actions and measures
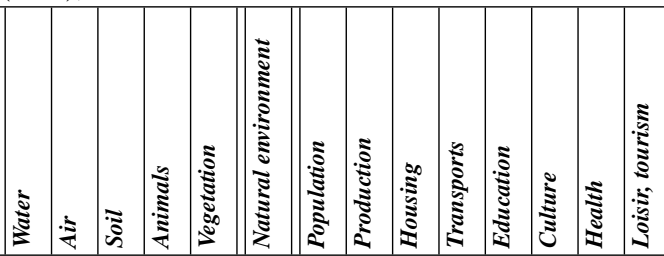

Limit the intervention zone

State the parcels affected by the inter-

vention

Get approvals for terrain expropriation

Terrain expropriation

Elimination

Foresee of an adequate number

work places

Relocation of the populatio

Detour motorised circulation

Demolish low value hazardous build-

ings

free spaces

Relocation of proposed buildings
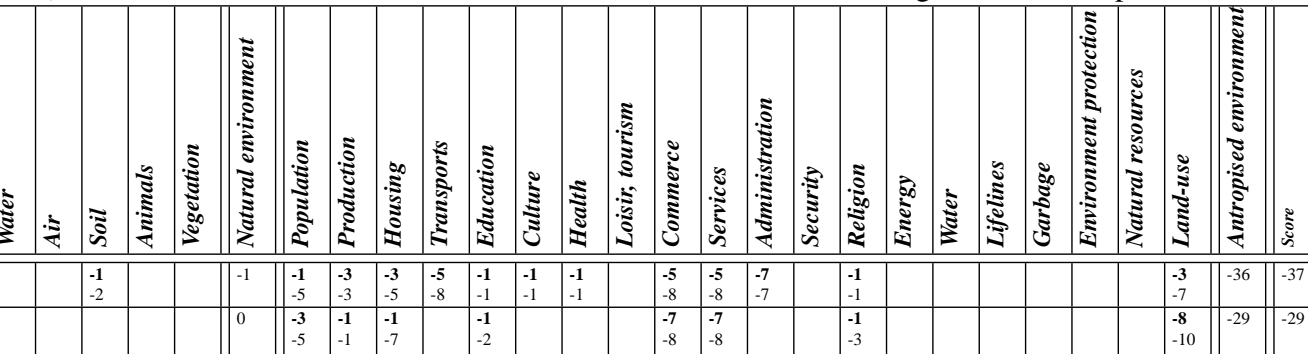

Connection of the new parcels to the

lifelines

Execution of the road

Furnishing of the street crossings

New transport routes

New buildings

Extensions of existing buildings

Restoration of existing valuable build-

ings

Completing the vegetation and fur-

nishing of green spaces

Furnishment of pedestrian zones

Furnishment of parking places

Furnishment of underground or over-

ground pedestrian passages

Score sum

Inform about positive effects

a. Set-up of information offices

b. Media centre to integrate inform

tion to/from population

Regroup the operation order to first see

the positive effects

Avoid selling buildings affected by the

operation to tenants

Stimulate built stock recycling:

a. Evaluate extension potential

a. Evaluate extension potential
b. Stimulate (tax relief) a certain con-

struction formul

c. Stimulate (sponsoring) to use and

renew existing buildings

d. Stimulate (special permits) the raise

\begin{tabular}{l} 
of terrain occupation \\
\hline Assure new and adequate working
\end{tabular}

places

Qualitatively improved furnish:

a. Pedestrian pavement

b. Silent transport means

c. Parking on secondary streets within

alignment vegetation

d. Lifeline development support by the

new business centres

Reconfigure the parcours in vertica

systematisation

Score sum

Offer flexibility in new residences/ of-

fices

Restore/renew valuable existing build-

ings

Condominiums conditioned by the

neighbourhood conditions

\begin{tabular}{|lllll|l|lll|l|l|l|l|l|l|l|l|}
$-\mathbf{2}$ \\
\end{tabular}

\begin{tabular}{|l|l|}
\hline-8 & -7 \\
\hline-7 & \\
-8 & \\
\hline-3 & -3 \\
-5 & -5 \\
\hline & -7 \\
& -10 \\
\hline+3 & +3 \\
-1 & -1 \\
\hline
\end{tabular}

\begin{tabular}{l|l|l|}
$\mathbf{+ 5}$ & $\mathbf{+ 5}$ & $\mathbf{+ 7}$ \\
+3 & +3 & +10
\end{tabular}

\begin{tabular}{|l|l|l|l|l|l|l|l|l|l|}
\hline-1 & & & & & & & -3 & -36 & -37 \\
-1 & & & & & & & -7 & & \\
\hline-1 & & & & & & & -8 & -29 & -29 \\
-3 & & & & & & & -10 & & \\
\hline & & & & & & & & -19 & -19 \\
\hline
\end{tabular}

(1)

\begin{tabular}{|l|l|l|l|l|}
$\mathbf{+ 5}$ & $+\mathbf{5}$ & $\mathbf{+ 5}$ & $\mathbf{+ 5}$ & $\mathbf{+ 9}$ \\
+6 & +6 & +6 & +6 & +10 \\
\hline & & & & +4
\end{tabular}

\begin{tabular}{|l||l||l|}
\hline-7 & -29 & -31 \\
-9 & & \\
\hline
\end{tabular}

\begin{tabular}{|l|l|l|l|l|l|l|l|l|l|l|l}
\hline & & +3 & & & & +8 & +8 & +8 & +6 & \\
\hline & -3 & & & -3 & $-\mathbf{5}$ & $\mathbf{- 1}$ & $\mathbf{- 5}$ & $\mathbf{- 3}$ & -1 \\
-10 & -1 & -8 & -4 & -2
\end{tabular}

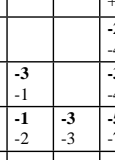

\begin{tabular}{l|l|l|l|}
$-\mathbf{2}$ & $\mathbf{- 2}$ & $\mathbf{- 3}$ & \\
-4 & -4 & -7 & \\
\hline & -3 & -3 &
\end{tabular}

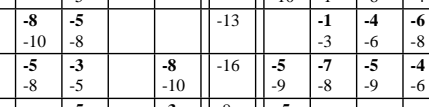

\begin{tabular}{|l|l|}
\hline-4 & -7 \\
\hline-3 & \\
-4 & \\
\hline-5 & -3 \\
-7 & -7 \\
\hline
\end{tabular}

\begin{tabular}{l|l|}
-7 & -7 \\
+3 & +3 \\
+1 & +1
\end{tabular}

\begin{tabular}{l|l|l|l|l|l|l|l|l|l|l} 
& -5 & & -3 & & +2 & & & & \\
\hline-5 & -5 & & -8 & -18 & +5 & +1 & -1 & +3 & -1
\end{tabular}

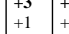

\begin{tabular}{|c|c|c|c|c|c|c|c|c|c|c|c|c|c|c|c|c|}
\hline & -8 & -8 & & -10 & & -1 & +1 & -4 & +5 & -3 & & & -8 & -8 & -9 & -9 \\
\hline $\begin{array}{l}+\mathbf{+ 1 0} \\
+10\end{array}$ & $\begin{array}{l}+8 \\
+8\end{array}$ & $\begin{array}{l}+5 \\
+8\end{array}$ & & & 23 & $\begin{array}{l}+5 \\
+5\end{array}$ & $\begin{array}{l}+2 \\
+2\end{array}$ & \begin{tabular}{|l|}
+8 \\
+8
\end{tabular} & & & $\begin{array}{l}+\mathbf{+ 8} \\
+8\end{array}$ & $\begin{array}{l}+\mathbf{8} \\
+8\end{array}$ & $\begin{array}{l}+\mathbf{+ 8} \\
+10\end{array}$ & \begin{tabular}{|l|}
+8 \\
+10
\end{tabular} & $\begin{array}{l}+8 \\
+10\end{array}$ & \begin{tabular}{|l|l}
$\mathbf{+ 8}$ \\
+10
\end{tabular} \\
\hline \begin{tabular}{|l|}
+1 \\
-1 \\
\end{tabular} & $\begin{array}{l}+8 \\
-1 \\
\end{array}$ & \begin{tabular}{|l|}
+1 \\
-1
\end{tabular} & \begin{tabular}{|l|}
+1 \\
-1
\end{tabular} & \begin{tabular}{|l|}
-3 \\
-5
\end{tabular} & 8 & & $\begin{array}{l}+\mathbf{+} \\
+2\end{array}$ & $\begin{array}{l}+5 \\
+3\end{array}$ & $\begin{array}{l}+\mathbf{+ 8} \\
+10\end{array}$ & & $\begin{array}{l}+5 \\
+3\end{array}$ & $\begin{array}{l}+\mathbf{5} \\
+3\end{array}$ & $\begin{array}{l}+3 \\
+1\end{array}$ & & \begin{tabular}{|l}
+3 \\
+1
\end{tabular} & \\
\hline
\end{tabular}

\begin{tabular}{|l|l|l|l|l|l||l|l|l|l|}
$\mathbf{+ 1}$ & $\mathbf{+ 8}$ & $\mathbf{+ 1}$ & $\mathbf{+ 1}$ & $\mathbf{- 3}$ & 8 & & $\mathbf{+ 2}$ & $\mathbf{+ 8}$ \\
-1 & -1 & -1 & -1 & -5 & & & +2 & +3 & +10
\end{tabular}

\begin{tabular}{l|l|l}
$+\mathbf{5}$ & $+\mathbf{5}$ \\
+3 & +3
\end{tabular}

\begin{tabular}{l|l|}
$+\mathbf{8}$ \\
+10
\end{tabular}

\begin{tabular}{|l|l|l|l|l|l|l|l|l|l|}
\hline-1 & +1 & & +1 & & & & & +10 \\
\hline $\mathbf{+ 8}$ & $-\mathbf{3}$ & & $-\mathbf{1}$ & 4 & & $\mathbf{+ 3}$ & $\mathbf{+ 2}$ & $\mathbf{+ 8}$ \\
+3 & -1 & & -1 & & & +3 & -1 & +9 \\
\hline
\end{tabular}

\begin{tabular}{lllll|l|l|l|l|l} 
& +3 & -1 & & -1 & & & +3 & -1 & +9 \\
\hline$-\mathbf{3}$ & $\mathbf{- 5}$ & $\mathbf{- 3}$ & $\mathbf{- 3}$ & $\mathbf{- 8}$ & -22 & $\mathbf{+ 5}$ & $\mathbf{+ 5}$ & $\mathbf{- 2}$ & $\mathbf{- 1}$ \\
-3 & -7 & -5 & -1 & -7 & & +8 & +8 & +2 & -1 \\
$\mathbf{- 3}$ & $\mathbf{- 5}$ & $\mathbf{- 5}$ & $\mathbf{- 3}$ & $\mathbf{- 1}$ & -17 & $\mathbf{+ 4}$ & $\mathbf{+ 4}$ & $\mathbf{- 1}$ &
\end{tabular}

\begin{tabular}{ll|l|l|l|l|}
+3 & +3 \\
+4 & +4
\end{tabular}

\begin{tabular}{l|l|l|l|l|l|}
\hline & & & & -1 \\
\hline+3 & & & & -2 \\
+4 & & & & -1 \\
\hline+3 & & & & +8 \\
\hline
\end{tabular}

\begin{tabular}{|l|l|l|l|l|l|l|l|l|}
-1 & & & & & & & 7 & 14 \\
\hline-2 & & & -1 & +4 & & -1 & 19 & 23 \\
\hline
\end{tabular}

\begin{tabular}{ll|l|l|l|l|l|l|l}
-3 & -5 & -5 & -3 & -1 & -17 & +4 & +4 & -1 \\
+1 & -7 & -1 & -1 & -1 & & +9 & +3 \\
+3
\end{tabular}

\begin{tabular}{ll|l|l|l|l|l|l|l|l}
$-\mathbf{1}$ & $+\mathbf{1}$ & & $-\mathbf{3}$ & $-\mathbf{1}$ & -4 & & & $+\mathbf{+ 5}$ & \\
+1 & +3 & & -1 & +3 & & & +8 & \\
\hline
\end{tabular}

\begin{tabular}{|l|l|l|l|l|l}
$+\mathbf{8}$ & $\mathbf{+ 8}$ & $\mathbf{+ 5}$ & $\mathbf{+ 5}$ & $\mathbf{+ 1 0}$ & 36 \\
$\mathbf{+ 1 0}$ & $\mathbf{1 0}$ & $\mathbf{+ 8}$ & $\mathbf{+ 3}$ & +10 &
\end{tabular}

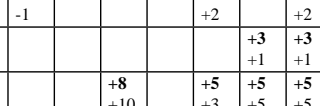

\begin{tabular}{ll|l|l|l|}
\hline+8 & +8 & +8 & +8 & +5 \\
+10 & +10 & +10 & +10 & +5
\end{tabular}

\begin{tabular}{l|l|l|l|l|l}
+10 & +10 & +10 & +10 & +5 \\
\hline+7 & +7 & +7 & +7 & +7 \\
+10 & +10 & +10 & +10 & +8
\end{tabular}

\begin{tabular}{|l|l|l|}
\hline+8 & 58 & 36 \\
\hline+6 & & \\
\hline
\end{tabular}

\begin{tabular}{lllll|l|l|l|l}
+3 & +10 & +8 & +3 & +10 & & & & +7 \\
+9
\end{tabular}

\begin{tabular}{lll|l|l|l|l|l|l} 
& & & +10 & & +3 & +5 & +5 \\
\hline+7 & & & & & +8 & +5 & +5 \\
+9 & & & & & +10 & +3 & +3 \\
\hline
\end{tabular}

\begin{tabular}{l|l|l|l|l|}
+10 & +10 & +10 & +10 & +8 \\
\hline $\mathbf{+ 8}$ & $\mathbf{+ 8}$ & $\mathbf{+ 8}$ & $\mathbf{+ 8}$ & $\mathbf{+ 8}$ \\
+10 & +10 & +10 & +10 & +10
\end{tabular}

\begin{tabular}{|l|l|l|l|l||l|}
$+\mathbf{+ 5}$ & $\mathbf{+ 5}$ & $\mathbf{- 1}$ & $\mathbf{+ 3}$ & $\mathbf{+ 4}$ & 16 \\
+7 & +8 & +3 & +1 & +2 & \\
& $\mathbf{+ 3}$ & $\mathbf{+ 4}$ & & $\mathbf{+ 5}$ & 12 \\
& +1 & +3 & & +5 & \\
\hline-2 & & $\mathbf{- 3}$ & & $\mathbf{- 1}$ & -6 \\
+1 & & +2 & & +3 &
\end{tabular}

\begin{tabular}{|l|l|l|l|}
\hline$+\mathbf{9}$ & & $\mathbf{+ 1}$ & \\
+9 & & +2 & \\
$+\mathbf{+ 7}$ & & & \\
+8 & & & \\
\hline+9 & & & \\
\hline & & & \\
\hline
\end{tabular}

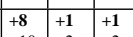

\begin{tabular}{lll|l|l|l}
+10 & +10 & +10 & +10 & +10 \\
\hline+1 & -1 & & +8
\end{tabular}

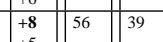

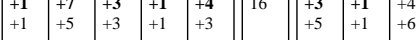

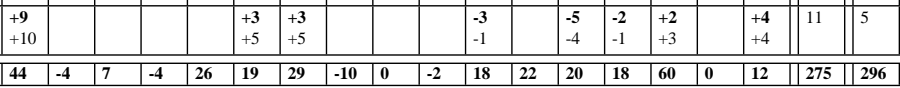

\begin{tabular}{|l|l|l|l|l|l|l|l|l|l|l|l|l|l|l|l|l|l|l|l|l|l|l|l|l|l|l|l|}
20 & 22 & -17 & 3 & -7 & 21 & 10 & 6 & 4 & 44 & -4 & 7 & -4 & 26 & 19 & 29 & -10 & 0 & -2 & 18 & 22 & 20 & 18 & 60 & 0 & 12 & 275 & 296 \\
\hline
\end{tabular}

Score sum

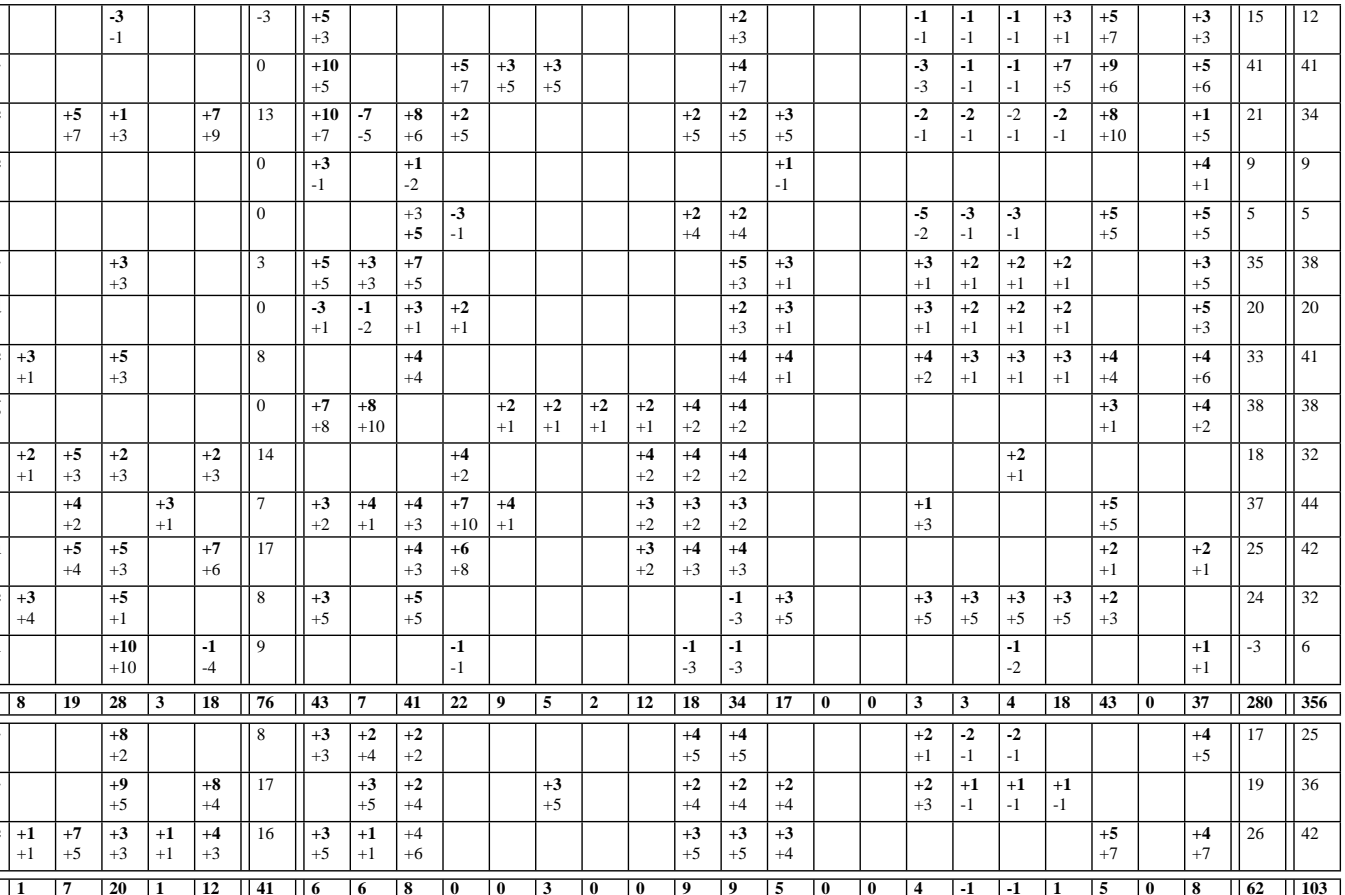


Lynch (1960), used in the urban risk management exercise in Bostenaru (2004e), in:

- "areas", homogenous functional divisions (ex. residential zone);

- "group" elements: typological grouping of urban elements (ex. the building stock);

- "point" elements: certain facilities or city symbols;

- "linear" elements: lifelines.

The sub-area wide division in "areas", at urban system functions level, and the typological one in "groups", at object system functions level, used in this study, on the background of both urban zoning and seismic microzonation, can be distinguished.

\section{Conclusions}

The town, fundamental element of the "urban-phenomenon", can be found today self-standing or included in complex territorial formations: urban agglomeration, conurbation or urban system (megalopolis/mega-city). Approaching urban agglomerations to mega-cities, or even the town today, relies on complex urban theory. The understanding of natural phenomena changed in time with the planning philosophy. Microzonation based on characteristic displacement spectra proves useful in the assessment of physical resilience. But, as earthquake resilience has more dimensions, zoning based on the seismic view is insufficient, and the urban zoning textures must be superposed on that, to get a complete view of resilience. For the vulnerability of the urban organism as settlement organisation form and the vulnerability from a sociology of architecture point of view, another textures have to be considered and these were identified through urban zoning. The inclusion of social components into earthquake engineering approaches in urban risk management was regarded from this background. It might be interpreted like if "earthquake engineering" is now longly no "engineering" only, or that it includes "social engineering" (Balamir, 2004). "Romanian town planning created a framework for the evolution of the urban organism that is still valid today" (Machedon and Scoffham, 1999). The locally adapted solutions from the interwar time proved sustainable. The complexity of the "urban-phenomenon" imposes an integrated multidisciplinary study.

Acknowledgements. The author thanks guest editor T. Glade, as well as I. A. Parvez and the other anonymous reviewer for the very useful suggestions during the revision of the manuscript. Infrastructure provided by Universität Karlsruhe (TH) used for editing all the material and insights during the $\mathrm{IAT}_{\mathrm{E}} \mathrm{X}$ introductory course by K. Braune are gratefully acknowledged.
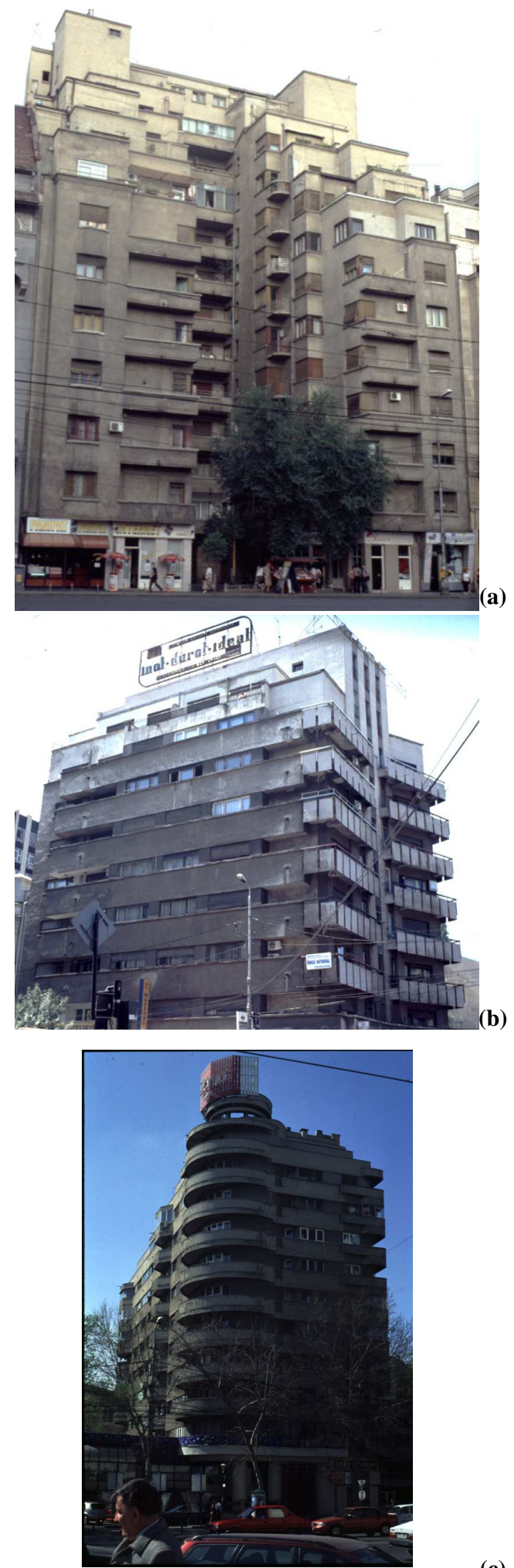

(c)

Fig. 7. Examples of post-1977-Vrancea-earthquake buildings in Bucharest (a) without changed conformation after retrofit ("Pherekyde"); (b) with changed conformation after retrofit ("Turist"); (c) replacing those collapsed ("Dunărea"). 


\section{References}

Ambraseys, N. N.: Long-period effects in the Romanian earthquake of March 1977, Nature, 268, 324-325, 1977.

Ambraseys, N. and Finkel, C.: The seismicity of Turkey and neighbouring regions, 1899-1915, Ann. Geophys., 5B, 701-726, 1987.

Ambraseys, N., Smit, P., Sigbjornsson, R., Suhadolc, P., and Margaris, B.: Internet-Site for European Strong-Motion Data, European Commission, Research-Directorate General, Environment and Climate Programme, 2002.

Ansal, A. M.: TG6 report: Seismic microzonation methodology, in: Proceedings of the 12th European Conference on Earthquake Engineering, London, UK, Paper \#830, 2002.

ATC-21: Rapid Visual Screening of Buildings for Potential Seismic Hazards: A Handbook, Applied Technology Council, Redwood City, California, 2nd Edition (1st edition 1988).

Bademli, R.: Earthquake mitigation and urban planning in Turkey, in: Komut, E. M.: Natural disasters: Designing for safety, Chamber of Architects of Turkey, Ankara, 58-64, 2001.

Balamir, M.: Urban seismic risk management: The Earthquake Master Plan of Istanbul (EMPI), in: Proceedings of the 13th World Conference on Earthquake Engineering, Vancouver, BC, Canada, Paper No. 9005, 2004.

Bohning, I.: Autonome Architektur und partizipatorisches Bauen, Birkhäuser, Basel, 1981.

Bonjer, K. P., Oncescu, M. C., Driad, L., and Rizescu, M.: A Note on Empirical Site Response in Bucharest, Romania, in: Vrancea Earthquakes: Tectonics, Hazard, and Risk Mitigation, edited by: Wenzel, F., Lungu, D., and Novak, O., Kluwer Academic Publ., 149-162, 1999.

Bostenaru Dan, M.: Early reinforced concrete frame condominium building with masonry infill walls designed for gravity loads only, in: EERI: World Housing Encyclopedia summary publication, Oakland, CA, USA, 2004a.

Bostenaru Dan, M.: A scientific world club, Science NextWave, nextwave.sciencemag.org/cgi/content/full/2004/09/09/11, 2004b.

Bostenaru Dan, M.: Economic efficiency and applicability of strengthening measures on buildings for seismic retrofit: An action guide, in: Disasters and Society, edited by: Malzahn, D. and Plapp, T., Logos Verlag Berlin, Berlin, 289-296, 2004c.

Bostenaru Dan, M.: Review of retrofit strategies decision system in historic perspective, Nat. Haz. Earth Sys. Sci., 4, 3, 449-462, 2004d, SRef-ID: 1684-9981/nhess/2004-4-449.

Bostenaru Dan, M.: Multi-criteria decision model for retrofitting existing buildings, Nat. Haz. Earth Sys. Sci., 4, 4, 485-499, 2004e, SRef-ID: 1684-9981/nhess/2004-4-485.

Bostenaru Dan, M. and Gehbauer, F.: Applicability and economic efficiency of seismic retrofit measures on historic buildings of mid-XXth century, in: Proceedings of the 13th World Conference on Earthquake Engineering, Vancouver, BC, Canada, Paper No. 3347, 2004.

Bruneau, M., Chang, S. E., Eguchi, R. T., Lee, G. C., O'Rourke, T. D., Reinhorn, A. M., Shinozuka, M., Tierney, K., Wallace, W. A., and von Winterfeldt, D.: A framework to quantitatively assess and enhance the seismic resilience of communities, Earthquake Spectra, 19, 4, 733-752, 2003.

Cardoso, R., Lopes, M., and Bento, R.: Earthquake resistant structures of Portuguese old "Pombalino" buildings, in: Proceedings of the 13th World Conference on Earthquake Engineering, Vancouver, BC, Canada, Paper No. 3329, 2004.
Chang, S. and Shinozuka, M.: Measuring improvements in the disaster resilience of communities, Earthquake Spectra, 20, 3, 739755, 2004.

Cioflan, C. O., Apostol, B. F., Moldoveanu, C. L., Panza, G. F., and Marmureanu, Gh.: Deterministic approach for the seismic microzonation of Bucharest, Pure and Applied Geophysics, 161, 1149-1164, 2004.

Coburn, A. and Spence, R.: Earthquake Protection, John Wiley and Sons, West Sussex, 2002 (2nd edition, 1st edition 1992).

Congress Internationaux d'Architecture moderne (CIAM): La Charte d'Athenes or The Athens Charter, 1933, Paris, France: The Library of the Graduate School of Design, Harvard University, http://www.getty.edu/conservation/research_resources/ charters/charter04.html, 1946.

Crowley, H., Pinho, R., and Bommer, J. J.: A Probabilistic Displacement-based Vulnerability Assessment Procedure for Earthquake Loss Estimation, Bulletin of Earthquake Engineering, 2, 2, 173-219, 2004.

Daraban, D.: Contribuţii metodologice şi legislative la reabilitarea fondului construit existent, Editura Semne, Bucureşti, 2000.

Faccioli, E. and Pessina, V.: WP2 - Basis of a handbook of earthquake ground motions scenarios, ftp://ftp.brgm.fr/, 2003.

FEMA: Hazus 99 (SR2), Technical Manual, Federal Emergency Management Agency, Washington DC, 1999.

Fiedrich, F.: Ein High-Level-Architecture-basiertes Multiagentensystem zur Ressourcenoptimierung nach Starkbeben, Universität Karlsruhe (TH), Institute for Technology and Management in Construction, Doctoral Dissertation, 2004.

Garcia Acosta, V.: Historia y desastres en America Latina, Red de Estudios en Prevencion de Desastres en América Latina, La Red, http://www.desenredando.org, 1997.

Glaister, S. and Pinho, R.: Development of a simplified deformation-based method for seismic vulnerability assessment, Journal of Earthquake Engineering, 7, SI 1, 107-140, 2003.

Greene, M. R.: Skopje, Yugoslavia: Seismic concerns and land use issues during the first twenty years of reconstruction following a devastating earthquake, Earthquake Spectra, 3, 1, 103-117, 1987.

Gülersoy, N. Z., Özsoy, A.: Housing and earthquake: An example of a graduate programme, in: Komut, EM: Natural disasters: Designing for safety, Chamber of Architects of Turkey, Ankara, 101-116, 2001.

IBA: Die Internationale Bauaustellung Emscher Park (1989-1999), http://www.iba.nrw.de, 1999.

Joedicke, J.: Angewandte Entwurfsmethodik für Architekten, Karl Krämer, Stuttgart, 1976.

Lungu, D. M., Scherer, R. J., Zsohar, M., and Coman, O.: On the Phenomenon of Long Periods of Ground Vibration During the 1990, 1986 and 1977 Earthquake Records from Vrancea Source, in: Earthquake Resistance Construction and Design 1, edited by: Savidis, S. A. and Balkema, A. A., Rotterdam, 51-59, 1994.

Lynch, K.: The image of the city, MIT Press, Cambridge MA, 2000 (27th edition, 1st edition 1960).

Machedon, L. and Scoffham, E.: Romanian Modernism, MIT Press, 1999.

Mândrescu, N. and Radulian, M.: Seismic Microzoning of Bucharest (Romania): A Critical Review, In: Vrancea Earthquakes: Tectonics, Hazard, and Risk Mitigation, Edited by: Wenzel, F., Lungu, D., and Novak, O., Kluwer Academic Publ., 109-122, 1999.

Markus, M., Fiedrich, F., Leebmann, J., Schweier, C., and Steinle, E.: Concept for an integrated Disaster Management Tool, in: 
Proceedings of the 13th World Conference on Earthquake Engineering, Vancouver, BC, Canada, Paper No. 3094, 2004.

Masure, P. and Lutoff, C.: Methodology on Urban System Exposure (USE) Assessment to Natural Disasters, ftp://ftp.brgm.fr/, 2003.

MLPAT: Normativ pentru proiectarea antiseismica a construcțiilor de locuinţe, social-culturale, agrozootehnice şi industriale, $\mathrm{P}$ 100-92, INCERC, Bucharest, Romania, 1994.

Moldoveanu, C. L., Radulian, M., Marmureanu, Gh., and Panza, G. F.: Microzonation of Bucharest: State-of-the-art, Pure and Applied Geophysics, 161, 1125-1147, 2004.

Mouroux, P., Betrand, E., Bour, M., Le Brun, B., Depinois, S., Masure, Ph., and the RISK-UE team: The European RISK-UE project: An advanced approach to earthquake risk scenarios, in: Proceedings of the 13th World Conference on Earthquake Engineering, Vancouver, BC, Canada, Paper No. 3329, 2004.

Panza, G. F., Romanelli, F., and Vaccari, F.: Seismic wave propagation in Laterally heterogeneous anelastic media: theory and application to seismic zonation, edited by: Dmowska, R., and Saltzman, B., Advances in Geophysics, Academic Press, San Diego, USA 43, 1-95, 2001.

Parvez, I. A., Vaccari, F., and Panza, G. F.: Site-specific microzonation study in Delhi metropolitan city by 2-D modelling of SH and P-SV waves, Pure and Applied Geophysics, 161, 11651184,2004
Prager, E.: Betonul armat în România. Editura Tehnică, Bucharest, 1979.

Sandi, H., Cornea, I., Căpăţînă, D., and Negru, R.: Studies in the 4 March 1977 earthquake, In: Cutremurul de pamânt din România de la 4 martie 1977, Edited by: Bălan, Ş, Cristescu, V., and Cornea, I., Academia Republicii Socialiste România, 439-498, 1982.

Sandi, H. and Perlea, V.: Engineering Study on Ground Motion, In: Cutremurul de pamânt din România de la 4 martie 1977, edited by: Bălan, Ş, Cristescu, V., and Cornea, I., Academia Republicii Socialiste România, 137-221, 1982.

Savic, N. V.: Planning and reconstruction of urban settlements after a devastating earthquake in: Komut, E. M.: Natural disasters: Designing for safety, Chamber of Architects of Turkey, Ankara, 89-100, 2001.

Soloviev, A. A., Vorobieva, I. A., and Panza, G. F.: Modelling of Block Structure Dynamics for the Vrancea Region: Source Mechanism of the Synthetic Earthquakes, Pure and Applied Geophysics, 157, 97-110, 2000.

Wenzel, F.: Strong earthquakes: A challenge for geosciences and engineering - A new collaborative research center in Germany, Seismol. Res. Lett., 68, 3, 439-443, 1997. 